\title{
The influence of some starter cultures and GDL on the formation of biogenic amines in dry sausages
}

\author{
Rittta Maijala, Susanna Eerola, Pauli Hill and Esko Nurmi
}

Majala, R., Eerola, S., Hill, P. \& Nurmi, E. 1993. The influence of some starter cultures and GDL on the formation of biogenic amines in dry sausages. Agric. Sci. Finl. 2: 403-412. (National Veterinary and Food Institute, FIN-00101 Helsinki, Finland and College of Veterinary Medicine, FIN-00581 Helsinki, Finland.)

The influence of five common starter cultures and glucono-delta-lactone (GDL) on the formation of histamine, tyramine, putrescine, cadaverine, spermine and spermidine in dry sausages was studied. Sausages were manufactured in a pilot plant from two different batches of raw material. No major differences were observed between the starter cultures studied in the biogenic amine levels detected during ripening. The lowest levels of histamine were detected in sausages fermented by GDL and Staphylococcae with or without lactic acid bacteria as a starter culture. In pure culture studies performed with a turbidometric method in MRS broth, non-starter lactic acid bacteria isolated from sausages were found to be more sensitive to acidic conditions than the starter strains used in the study. The addition of $2 \%$ histidine to MRS broth resulted in a tremendous increase in histamine production (from 1-2 to $6000 \mathrm{ppm}$ ). However, in histidine-fortified MRS broth with GDL addition, only $54 \mathrm{ppm}$ of histamine was formed. According to these results, the $\mathrm{pH}$ decrease caused by GDL addition decreases histamine formation in dry sausages and in MRS broth. The differences in $\mathrm{pH}$ decrease may be one reason for the very varying concentrations of histamine detected in retail dry sausages.

Keywords: fermentation, histamine, tyramine

\section{Introduction}

Over 30 years ago the beneficial influence of added starter cultures was shown to improve and to stabilize the quality of dry sausages. NiINIVAARA (1955) recommended the use of micrococci as a starter culture (resulting in the development of Baktoferment 61) and NURMI (1966) used a combination of Lactobacillus plantarum with micrococcae (resulting in the development of Duploferment 66). Since then, many new starter cultures have been developed. However, lactic acid bacteria are still used in most combinations of dry sausage manufacture.

There are several reports of high levels of bio- genic amines in fermented sausages obtained from retail markets (RICE et al. 1975, VANDEKERCKHOVE 1977, RAMANTANIS 1982, WORTBERG and Woller 1982, PeChanek et al. 1983, PfanNHAUSER and PECHANEK 1984, BAUER et al. 1989, TSCHABRUN et al. 1990). Factors such as starter cultures, raw material and $\mathrm{pH}$ decrease, which affect the formation of biogenic amines during sausage fermentation, are not yet fully understood. It is therefore difficult to make improvements in sausage fermentation as long as the critical points still remain largely unascertained.

Biogenic amines are basic nitrogenous compounds mainly formed by decarboxylation of 
amino acids or by amination and transamination of aldehydes and ketones (MAGA 1978, PFANNHAUSER and PeChANEK 1984, ASKAR and TREPTOW 1986). Some aromatic and heterocyclic amines, such as tyramine, histamine and phenylethylamine, have vasoactive properties making their presence in food a potential public health concern (IENISTEA 1971, LÜTHY and SCHLATTER 1983, TAYLOR 1983, ASKAR and TREPTOW 1986, MONERET-VAUTRIN 1985). The aliphatic diamines, putrescine and cadaverine, as well as the polyamines, spermine and spermidine, occur universally in animals and plants, and at least putrescine and spermidine are found in most bacteria. They are important in the regulation of nucleic acid function and protein synthesis, and probably also in the stabilization of membranes (SMITH 1981). They also potentiate the effect of histamine (BJELDANES et al. 1978).

In an earlier study the $\mathrm{pH}$ decrease caused by addition of GDL decreased significantly the formation of histamine in minced meat. The lower was the $\mathrm{pH}$ on the first day of incubation, the less amines were formed (MAIJALA et al. 1993). GDL hydrolyzes spontaneously in water to gluconic acid and causes a decrease in pH. It is used in the meat industry for dry sausage manufacture, especially with starter cultures which do not contain lactic acid bacteria (LAB). However, the addition of GDL can sometimes be detrimental to flavour and accelerate the development of rancidity (LÜCKE and HECHELMAN 1986). The purpose of this work was to study biogenic amine formation in sausages fermented by five common starter cultures in Finland. The effect of accelerated $\mathrm{pH}$ decrease in dry sausages was also studied in the second trial by adding different GDL and glucose combinations to the sausages.

\section{Material and methods}

\section{Sausage manufacture}

The sausages were prepared from frozen meat originating from one cutter of a commercial meat plant ( $82 \mathrm{~kg}$ pork, 55 pork fat, $69 \mathrm{~kg}$ beef and 3\%
$\mathrm{NaCl})$. The mass was divided into five samples and processed in a Seydelmann cutter (K41) with addition of sodium nitrite $\left(\mathrm{NaNO}_{2}\right)$ as a $10 \%$ aqueous solution (60 ppm), $\mathrm{KNO}_{3} 120 \mathrm{ppm}$, ascorbic acid $(0.025 \%)$ and spices.

To the sausages fermented by Baktoferment 61 (Rudolf Müller \& co., Germany), containing Staphylococcus carnosus $\mathrm{MIII}, 0.7 \%$ GDL and $0.15 \%$ glucose were added. In the other sausages, $0.6 \%$ of glucose (series a) was used together with one of four different starter cultures: Duploferment 66 (Rudolf Müller \& co.) containing S. carnosus and Lactobacillus plantarum (1), Pentoferment 85 (Rudolf Müller \& co.) containing S. carnosus and Lactobacillus pentosus (2), Condi-Rasant 820/10 (Gewürzmüller, Germany) containing Staphylococcus spp. and Pediococcus pentosaceus (3) or Flora-Carn SL (Chr. Hansen's Lab., Denmark) containing $S$. carnosus and L. pentosus (4). The pure LAB strains isolated from these starter cultures had previously been found to be histamine- and tyramine-negative in fortified MRS broth (MAIJALA 1993). The pure strains of Staphylococcus were also found to be histamine- and tyraminenegative with a similar method in trypticase soy broth.

This trial was repeated twice. In the second trial, different levels of addition of GDL (Finnsugar Bioproducts, Finland) together with glucose were studied in conjunction with the starter cultures 1-4. Each sample was divided into three subsamples designated a, b and c. No GDL but $0.6 \%$ glucose was added to the samples (a) as in the first trial, $0.25 \% \mathrm{GDL}$ and $0.4 \%$ glucose were added to samples (b), and $0.5 \%$ GDL and $0.20 \%$ glucose to samples (c). The sausages (weight $300 \mathrm{~g}$, diameter $60 \mathrm{~mm}$ ) were stuffed into fibrous casings and ripened for 2 days at $23^{\circ} \mathrm{C}(93 \% \mathrm{rh}), 1$ day at $21^{\circ} \mathrm{C}$ ( $85 \% \mathrm{rh})$ and then for 4 days at $20^{\circ} \mathrm{C}(85 \% \mathrm{rh})$. The remainder of the ripening and storage for up to 7 weeks was at $10^{\circ} \mathrm{C}(70 \%$ rh). The sausages were lightly smoked during days 1-5.

\section{Microbiological and chemical analyses}

One sausage from each sausage type (B,1-4) was taken as a sample 6 times during ripening. The 
cover was cleaned with $70 \%$ ethanol and removed aseptically. The whole sausage was cut into small pieces and homogenized mechanically. Thereafter the mass was mixed well and samples were taken for analysis of biogenic amines and microbiological content and for measurement of $\mathrm{pH}$ and $\mathrm{a}_{\mathrm{w}}$.

$\mathrm{pH}$ values were measured directly from the samples using an Orion Research Incorporated SA $520 \mathrm{pH} / \mathrm{mV}$ meter equipped with a Ross ${ }^{\mathrm{TM}} \mathrm{pH}$ electrode no. 8163 (Switzerland). After a 2-h adaptation period $\mathrm{a}_{w}$ values were obtained at $25^{\circ} \mathrm{C}$ from a sample of 25-30 g using a Rotronic Hygroskop (Fattore Vitale \& Co, Italy). A $10 \mathrm{~g}$ sample of mixed sausage was serially diluted with a diluent containing $0.1 \%$ peptone and $0.85 \% \mathrm{NaCl}$ in sterile deionized water. Coliforms were counted on Violet Red Bile Agar (VRB, Orion; ISO 4832), fecal streptococci on Slanetz-Bartley agar (SB, Oxoid, NCFA 68), moulds and yeasts on Malt extract agar (Oxoid) with added chlortetracycline $(100 \mathrm{mg} / \mathrm{l})$ and chloramphenicol (100 mg/l), Staphylococcae on blood agar base (BBL) containing 5\% defibrinated blood and LAB on de Man, Rogosa and Sharpe agar with sorbic acid (MRS-S, MRS of LAB $\mathrm{M}$ with added sorbic acid of Fluka, incubated at $20-22^{\circ} \mathrm{C}$ for 5 days anaerobically). Biogenic amines were determined using the HPLC method of EEROLA et al. (1993). The detection limits were $1 \mathrm{mg} / \mathrm{kg}$ for tyramine, histamine, spermine, spermidine and cadaverine and $2 \mathrm{mg} / \mathrm{kg}$ for putrescine.

\section{Histamine production by pure cultures}

The influence of low $\mathrm{pH}$ achieved with GDL or by the initial addition of lactic acid was studied by a turbidometric method. At the same time the $\mathrm{pH}$ values were monitored in similar cultures maintaned in small tubes at $30^{\circ} \mathrm{C}$. Histamine was analyzed from tubes by HPLC after 5 days of incubation. Because no major differences were observed between the growth patterns of the four starter cultures, one strain (GS-11) isolated from Duploferment 66 ( $L$. plantarum) was selected to represent the starter cultures. Two non-starter lactic acid bacteria (NSLAB) isolated from the sausages during ripening were also used. G-106 produced $930 \mathrm{ppm}$ histamine and 920 ppm tyramine and G-261 produced $<1 \mathrm{ppm}$ histamine and $400 \mathrm{ppm}$ tyramine in fortified MRS broth (MAJALA 1993).

LAB strains (preserved at $-75^{\circ} \mathrm{C}$ ) were incubated in MRS broth (Oxoid) at $30^{\circ} \mathrm{C}$ for $24 \mathrm{~h} .100 \mu \mathrm{l}$ of this culture was inoculated into a fresh MRS broth and incubated at $30^{\circ} \mathrm{C}$ for exactly $24 \mathrm{~h}$. These cultures were used for turbidometric inoculations. The cell densities $(\mathrm{cfu} / \mathrm{ml})$ of the cultures were determined by culturing serial dilutions on MRS-S plates. $10 \mu \mathrm{l}$ of a $10^{-1}$ dilution of MRS-broth cultures $\left(\log _{10} 8 \mathrm{cfu} / \mathrm{ml}\right)$ was added to the wells of Honeycomb plates, each containing $390 \mu$ of basic broth. As a basic broth either pure MRS broth, MRS broth with lactic acid ( $\mathrm{pH} 4.7$ ) or MRS broth with GDL ( $1 \%$ or $2 \%$ ), all with or without L-histidinemonohydrochloride (Merck 4350), were used. Three replicate wells were used both for the samples and for the negative controls. The cuvettes were incubated in a data logging turbidometer incubator (Bioscreen $^{\mathrm{R}}$, Labsystems Oy, Finland) at $30^{\circ} \mathrm{C}$ for $120 \mathrm{~h}$. The filter giving the lowest possible background absorbance values was chosen $(600 \mathrm{~nm})$ and the optical density was measured at $30 \mathrm{~min}$ intervals.

\section{Results}

The levels of biogenic amines increased during ripening, as was reported e.g. by RAMANTANIS (1982) (Table 1). In both trials the final levels of tyramine were lowest in the sausages fermented by Baktoferment $61+$ GDL. However, the addition of GDL also decreased to some extent the tyramine levels detected in sausages fermented by Duploferment 66 and Flora-Carn SL (Fig. 1).

The influence of the raw material was especially clear on the formation of histamine. In the first trial hardly any histamine was detected but in the second trial the amounts increased up to $108 \mathrm{ppm}$. The lowest levels of histamine in the second trial were detected in the sausages fermented by Baktoferment $61+$ GDL and Flora-Carn SL (Table 1). Histamine levels also clearly decreased when GDL was added (Fig. 2). There were no major differ- 


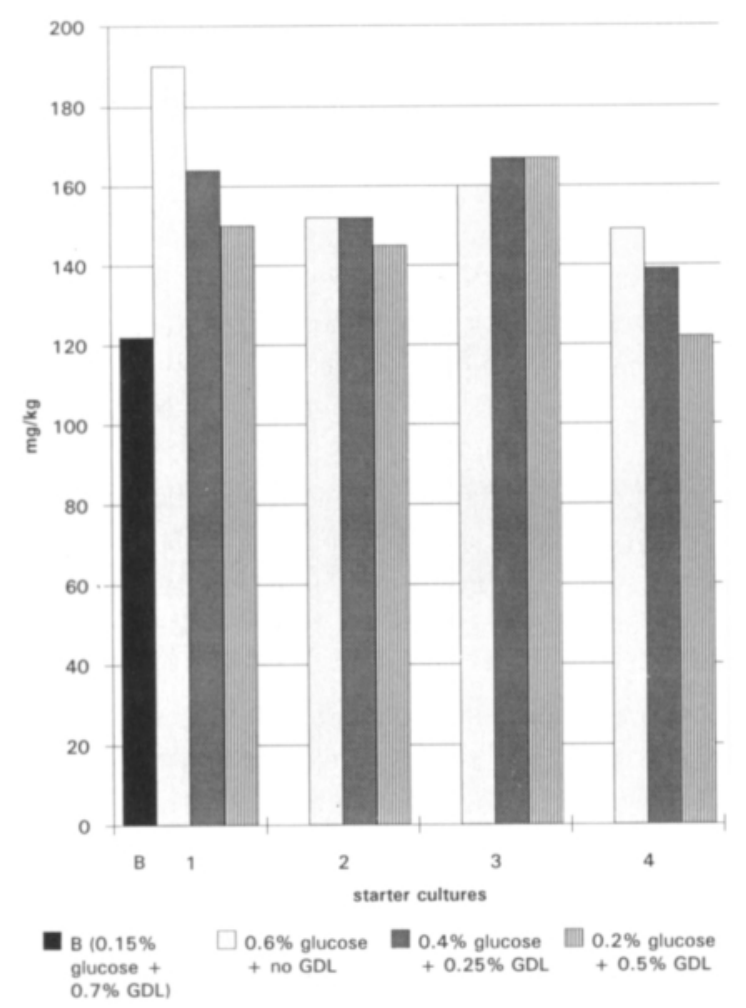

Fig. 1. Tyramine levels detected in sausages fermented with different GDL and glucose combinations. For starter cultures, see Table 2. The results of sausages fermented by B, 1 and 4 have been presented previously (MAIJALA and EEROLA 1993).

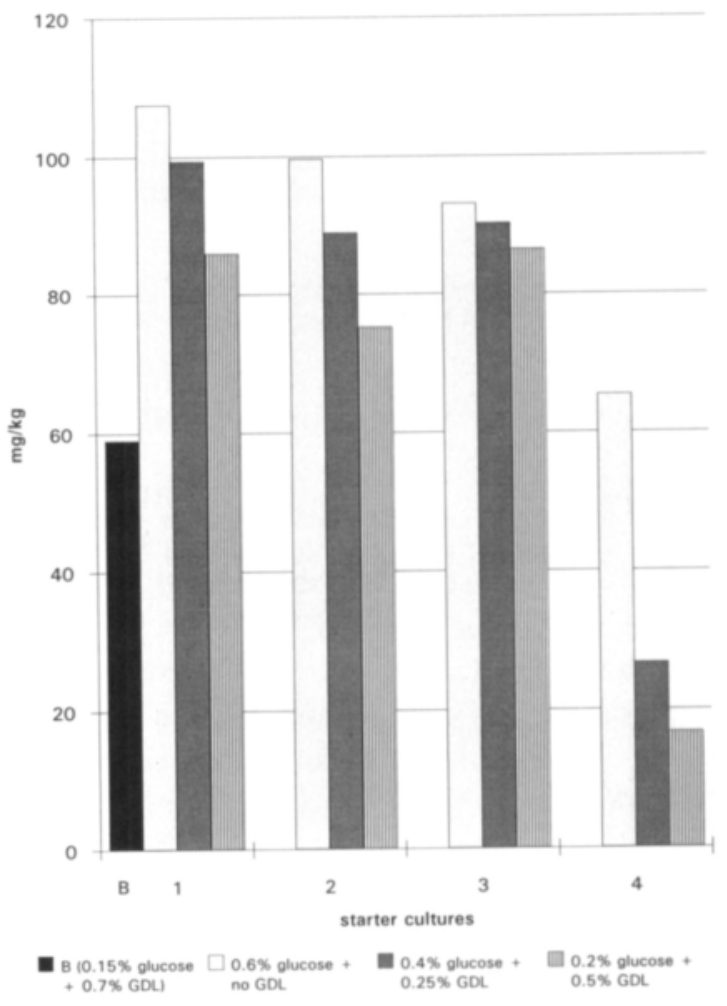

Fig. 2. Histamine levels detected in sausages fermented with different GDL and glucose combinations. For starter cultures, see Table 2. The results of sausages fermented by B, 1 and 4 have been presented previously (MAJALA and EEROLA 1993). ences between the starter cultures 1-4 regarding the levles of other amines during ripening.

In both trials the most rapid $\mathrm{pH}$ decrease was in the sausages fermented by Baktoferment $61+$ GDL, as expected. The addition of GDL with a smaller amount of glucose also lowered the $\mathrm{pH}$ values in the beginning of the fermentation (Table 2 ). There were no great differences between the $a_{w}$ values of different sausages during ripening. The $a_{w}$ values decreased from 0.98 to $0.90-0.93$ ( 21 days) and to $0.78-0.84$ (49 days) in these trials.

The results of LAB and Staphylococcus in sausages fermented with starter cultures 1-4 without GDL addition are presented in Table 3. The levels of coliforms were $<\log 1.0$ except in the raw material of the second trial $(\log 1.1)$. The levels of fecal streptococci $(<\log 3.1)$, yeasts $(<\log .4 .7)$ and
Bacillus spp. ( $<\log 3.6)$ also remained at the normal level for this type of product. No moulds were detected in any of the samples. The GDL addition had no influence on the bacterial counts measured.

In pure culture studies the NSLAB strains (G-106 and G-261) decreased the $\mathrm{pH}$ slowly as compared with the starter strain GS-11. However, the final $\mathrm{pH}$ values with all these strains were almost equal after 5 days of incubation in pure MRS broth (Table 4). GS-11 also grew much better than the NSLAB strains in pure MRS broth (Fig. 3-5). Acidification of MRS broth below $\mathrm{pH} 5.0$ with lactic acid or $1 \%$ GDL increased the lag time and decreased the growth rate of the NSLAB strains but not of GS-11. Furthermore, the addition of $2 \%$ GDL with or without histidine to MRS broth prevented the growth of NSLAB during five days of 
Table 1. Amounts of biogenic amines during the ripening of dry sausages in two trials ( $\mathrm{mg} / \mathrm{kg}$ ). B and the numbers 1-4 refer to the different starter cultures used, see Table 2. $(\mathrm{a}=0.6 \%$ glucose + no glucono-delta-lactone, $\mathrm{n} . \mathrm{d} .=$ not detected $)$.

\begin{tabular}{|c|c|c|c|c|c|c|c|c|c|c|c|}
\hline & & Firs & & & & & Seca & ial: & & & \\
\hline & Day & B & la & $2 a$ & $3 \mathrm{a}$ & $4 a$ & B & $1 \mathrm{a}$ & $2 a$ & $3 \mathrm{a}$ & $4 a$ \\
\hline Histamine & 0 & 1 & 1 & 1 & 1 & 1 & 2 & 2 & 2 & 2 & 2 \\
\hline & 3 & 2 & 2 & 2 & 3 & 2 & 2 & 5 & 2 & 5 & 4 \\
\hline & 7 & 2 & 2 & 2 & 2 & 2 & 1 & 46 & 39 & 41 & 9 \\
\hline & 21 & 4 & 4 & 3 & 3 & 3 & 43 & 71 & 73 & 66 & 16 \\
\hline & 35 & 5 & 4 & 4 & 4 & 3 & 59 & 104 & 104 & 98 & 29 \\
\hline & 49 & 8 & 4 & 4 & 4 & 4 & 59 & 108 & 100 & 93 & 65 \\
\hline Tyramine & 0 & n.d. & n.d. & n.d. & n.d. & n.d. & 1 & 1 & 1 & 1 & 1 \\
\hline & 3 & n.d. & 3 & 5 & 7 & 8 & 12 & 14 & 10 & 13 & 10 \\
\hline & 7 & 16 & 59 & 74 & 68 & 71 & 60 & 91 & 102 & 99 & 42 \\
\hline & 21 & 37 & 101 & 119 & 107 & 104 & 93 & 117 & 120 & 117 & 86 \\
\hline & 35 & 55 & 129 & 143 & 146 & 120 & 113 & 149 & 146 & 144 & 133 \\
\hline & 49 & 76 & 146 & 148 & 166 & 129 & 122 & 190 & 152 & 160 & 149 \\
\hline Putrescine & 0 & 8 & 8 & 8 & 8 & 8 & 17 & 17 & 17 & 17 & 17 \\
\hline & 3 & 6 & 5 & 5 & 4 & 4 & n.d. & 4 & 4 & 6 & 7 \\
\hline & 7 & 5 & 7 & 10 & 13 & 12 & 4 & 2 & n.d. & n.d. & 2 \\
\hline & 21 & 10 & 13 & 15 & 27 & 13 & 5 & 13 & 13 & 5 & 8 \\
\hline & 35 & 16 & 16 & 19 & 31 & 13 & 4 & 6 & 5 & 7 & n.d. \\
\hline & 49 & 31 & 23 & 25 & 41 & 18 & 5 & 9 & 15 & 17 & 17 \\
\hline Cadaverine & 0 & n.d. & n.d. & n.d. & n.d. & n.d. & 1 & 1 & 1 & 1 & 1 \\
\hline & 3 & n.d. & n.d. & n.d. & n.d. & n.d. & n.d. & 2 & 1 & 1 & 1 \\
\hline & 7 & n.d. & n.d. & n.d. & n.d. & n.d. & 2 & 4 & 5 & 5 & 2 \\
\hline & 21 & n.d. & 2 & n.d. & n.d. & 1 & 3 & 5 & 6 & 5 & 3 \\
\hline & 35 & n.d. & n.d. & n.d. & n.d. & n.d. & 3 & 8 & 8 & 6 & 4 \\
\hline & 49 & n.d. & n.d. & n.d. & n.d. & n.d. & 4 & 7 & 7 & 5 & 5 \\
\hline Spermidine & 0 & 3 & 3 & 3 & 3 & 3 & 2 & 2 & 2 & 2 & 2 \\
\hline & 3 & 3 & 3 & 3 & 4 & 3 & 3 & 4 & 3 & 3 & 3 \\
\hline & 7 & 2 & 2 & 3 & 3 & 4 & 2 & 2 & 2 & 3 & 3 \\
\hline & 21 & 3 & 3 & 4 & 4 & 4 & 2 & 3 & 2 & 2 & 3 \\
\hline & 35 & 4 & 4 & 5 & 4 & 4 & 3 & 3 & 3 & 3 & 4 \\
\hline & 49 & 5 & 5 & 6 & 6 & 5 & 3 & 3 & 3 & 3 & 4 \\
\hline Spermine & 0 & 22 & 22 & 22 & 22 & 22 & 24 & 24 & 24 & 24 & 24 \\
\hline & 3 & 25 & 22 & 22 & 24 & 22 & 22 & 22 & 21 & 22 & 20 \\
\hline & 7 & 16 & 10 & 27 & 24 & 27 & 17 & 19 & 24 & 22 & 22 \\
\hline & 21 & 19 & 21 & 30 & 26 & 31 & 19 & 20 & 21 & 22 & 20 \\
\hline & 35 & 28 & 29 & 29 & 28 & 29 & 21 & 24 & 24 & 26 & 24 \\
\hline & 49 & 38 & 32 & 35 & 35 & 33 & 24 & 28 & 24 & 26 & 29 \\
\hline
\end{tabular}

incubation, whereas GS11 showed only a slightly decreased growth curve as compared with the $1 \%$ GDL addition. Histamine was not produced by the strains GS-11 and G-261 in any of the broth compositions studied. G-106 produced 1 ppm histamine in pure MRS broth, $2 \mathrm{ppm}$ in pure MRS broth at $\mathrm{pH}$
4.7 and $11 \mathrm{ppm}$ in MRS + GDL. Addition of histidine resulted in a great increase of histamine in $\mathrm{MRS}+\mathrm{H}$ (5964 ppm) and MRS+H (pH 4.7) (6120 ppm). However, in MRS+H broth with GDL addition only $55 \mathrm{ppm}$ of histamine was detected. 
Table 2. $\mathrm{pH}$ values in sausages during fermentation in two trials. The starter cultures were Baktoferment 61 with $0.7 \%$ glucono-delta-lactone (GDL) and $0.15 \%$ glucose (B), Duploferment 66 (1), Pentoferment 85 (2), Condi-Rasant 820/10 (3) and Flora-Carn SL (4) with glucose/GDL combinations of $0.6 \%$ glucose (a), $0.4 \%$ glucose $+0.25 \%$ GDL (b) or $0.2 \%$ glucose + $0.5 \%$ GDL. ${ }^{*}=$ not studied.

\begin{tabular}{|c|c|c|c|c|c|c|c|}
\hline Code & Day 0 & Day 1 & Day 3 & Day 7 & Day 21 & Day 35 & Day 49 \\
\hline \multicolumn{8}{|c|}{ First trial: } \\
\hline B & 5.6 & 4.6 & * & 4.6 & 5.0 & 4.9 & 4.8 \\
\hline 1a & 5.6 & 5.8 & * & 4.8 & 5.0 & 5.0 & 4.9 \\
\hline $2 \mathrm{a}$ & 5.6 & 5.7 & * & 4.8 & 5.0 & 4.9 & 4.9 \\
\hline $3 \mathrm{a}$ & 5.6 & 5.7 & * & 4.4 & 4.8 & 4.8 & 4.6 \\
\hline $4 a$ & 5.6 & 5.8 & * & 4.8 & 4.9 & 4.9 & 4.9 \\
\hline \multicolumn{8}{|c|}{ Second trial: } \\
\hline B & 5.5 & 5.0 & 5.1 & 4.7 & 4.5 & 4.4 & 4.7 \\
\hline 1a & 5.5 & 5.5 & 5.4 & 4.8 & 4.6 & 4.5 & 5.1 \\
\hline $2 \mathrm{a}$ & 5.5 & 5.5 & 5.5 & 4.9 & 4.6 & 4.4 & 4.9 \\
\hline $3 a$ & 5.5 & 5.6 & 5.1 & 4.7 & 4.6 & 4.3 & 4.8 \\
\hline $4 a$ & 5.5 & 5.6 & 5.3 & 4.8 & 4.6 & 4.5 & 4.8 \\
\hline lb & 5.5 & 5.4 & 5.3 & 4.8 & 4.6 & 4.5 & 4.8 \\
\hline $2 b$ & 5.5 & 5.4 & 5.4 & 4.8 & 4.6 & 4.2 & 4.8 \\
\hline $3 b$ & 5.5 & 5.3 & 5.1 & 4.7 & 4.6 & 4.3 & 4.8 \\
\hline $4 b$ & 5.5 & 5.4 & 5.2 & 4.8 & 4.7 & 4.6 & 4.8 \\
\hline 1c & 5.5 & 5.2 & 5.2 & 4.9 & 4.7 & 4.5 & 4.8 \\
\hline $2 \mathrm{c}$ & 5.5 & 5.2 & 5.2 & 4.8 & 4.6 & 4.5 & 4.8 \\
\hline $3 \mathrm{c}$ & 5.5 & 5.2 & 5.1 & 4.8 & 4.6 & 4.5 & 4.8 \\
\hline $4 c$ & 5.5 & 5.2 & 5.1 & 4.8 & 4.7 & 4.5 & 4.9 \\
\hline
\end{tabular}

Table 3. Results of microbiological studies during the ripening of dry sausages $\left(\log _{10} \mathrm{cfu} / \mathrm{g}\right)$ in two trials. B and the numbers 1-4 refer to the different starter cultures used, see Table $2 .{ }^{*}=$ not studied.

\begin{tabular}{|c|c|c|c|c|c|c|c|c|c|c|c|}
\hline & \multirow[b]{2}{*}{ Day } & \multicolumn{3}{|c|}{ First trial: } & \multirow[b]{2}{*}{$3 \mathrm{a}$} & \multirow[b]{2}{*}{$4 a$} & \multicolumn{2}{|c|}{ Second trial: } & \multirow[b]{2}{*}{$2 \mathrm{a}$} & \multirow[b]{2}{*}{$3 a$} & \multirow[b]{2}{*}{$4 a$} \\
\hline & & B & 1a & $2 \mathrm{a}$ & & & B & 1a & & & \\
\hline \multirow{6}{*}{ Lactic acid bacteria } & 0 & 3.8 & 3.8 & 3.8 & 3.8 & 3.8 & 5.0 & 5.0 & 5.0 & 5.0 & 5.0 \\
\hline & 3 & $*$ & $*$ & $*$ & $*$ & $*$ & $*$ & $*$ & $*$ & $*$ & $*$ \\
\hline & 7 & 7.8 & 7.8 & 7.8 & 8.5 & 7.9 & $*$ & $*$ & $*$ & $*$ & $*$ \\
\hline & 21 & 7.7 & 7.5 & 7.8 & 8 & 7.5 & 8.3 & 8.6 & 8.7 & 8.2 & 7.7 \\
\hline & 35 & 7.7 & 7.5 & 7.6 & 7.7 & 7.4 & $*$ & $*$ & $*$ & $*$ & $*$ \\
\hline & 49 & 7.5 & 6.9 & 7.1 & 7.2 & 7 & 8.5 & 8.6 & 8.1 & 7.8 & 7.7 \\
\hline \multirow[t]{6}{*}{ Staphylococcus sp. } & 0 & $*$ & $*$ & $*$ & $*$ & $*$ & $*$ & $*$ & $*$ & $*$ & $*$ \\
\hline & 3 & $*$ & $*$ & $*$ & $*$ & $*$ & $*$ & $*$ & $*$ & $*$ & $*$ \\
\hline & 7 & 5.7 & 5.6 & 6 & 6.9 & 6.9 & $*$ & $*$ & $*$ & $*$ & $*$ \\
\hline & 21 & 5.7 & 5.6 & 5.7 & 6.7 & 6.7 & 5.2 & 5.8 & 5.5 & 6.3 & 6.3 \\
\hline & 35 & 5.5 & 5.6 & 5.4 & 6.1 & 6.1 & $*$ & $*$ & $*$ & $*$ & * \\
\hline & 49 & 5.7 & 5.3 & 5.8 & 6.5 & 6.5 & 5.1 & 5.5 & 5.3 & 5.5 & 5.7 \\
\hline
\end{tabular}


Table 4. pH values of two non-starter lactic acid bacteria strains (G-106 and G-261) and one starter lactic acid bacteria (GS-11) during incubation in six different combinations of de Man-Rogosa-Sharpe broth (MRS), histidine $(\mathrm{H})(2 \%)$ and glucono-deltalactone (GDL) (1\%).

\begin{tabular}{|c|c|c|c|c|c|c|}
\hline & $\begin{array}{c}\text { MRS } \\
\text { pH } 6.2\end{array}$ & $\begin{array}{c}\text { MRS + H } \\
\text { pH } 5.4\end{array}$ & $\begin{array}{c}\text { MRS } \\
\text { pH } 4.7\end{array}$ & $\begin{array}{c}\mathrm{MRS}+\mathrm{H} \\
\mathrm{pH} 4.7\end{array}$ & $\begin{array}{c}\text { MRS } \\
+ \text { GDL }\end{array}$ & $\begin{array}{c}\text { MRS + H } \\
+ \text { GDL }\end{array}$ \\
\hline \multicolumn{7}{|l|}{ G-106 } \\
\hline $1 \mathrm{~h}$ & 6.2 & 5.4 & 4.7 & 4.7 & 4.9 & 4.6 \\
\hline $5 \mathrm{~h}$ & 6.2 & 5.4 & 4.7 & 4.6 & 4.7 & 4.5 \\
\hline $21 \mathrm{~h}$ & 4.6 & 4.5 & 4.6 & 4.5 & 4.5 & 4.5 \\
\hline $27 \mathrm{~h}$ & 4.3 & 4.4 & 4.6 & 4.3 & 4.5 & 4.4 \\
\hline $120 \mathrm{~h}$ & 3.7 & 4.1 & 4.4 & 4.3 & 4.1 & 4.0 \\
\hline \multicolumn{7}{|l|}{ G-261 } \\
\hline $1 \mathrm{~h}$ & 6.2 & 5.3 & 4.6 & 4.7 & 4.8 & 4.6 \\
\hline $5 \mathrm{~h}$ & 6.2 & 5.3 & 4.6 & 4.7 & 4.7 & 4.5 \\
\hline $21 \mathrm{~h}$ & 4.4 & 4.3 & 4.6 & 4.5 & 4.5 & 4.4 \\
\hline $27 \mathrm{~h}$ & 4.2 & 4.1 & 4.5 & 4.3 & 4.5 & 4.4 \\
\hline $120 \mathrm{~h}$ & 3.8 & 3.6 & 4.3 & 3.8 & 4.3 & 4.0 \\
\hline \multicolumn{7}{|l|}{ GS-11 } \\
\hline $1 \mathrm{~h}$ & 6.2 & 5.3 & 4.6 & 4.7 & 4.8 & 4.5 \\
\hline $5 \mathrm{~h}$ & 5.9 & 5.3 & 4.6 & 4.7 & 4.7 & 4.5 \\
\hline $21 \mathrm{~h}$ & 3.9 & 3.8 & 4.1 & 3.9 & 3.8 & 3.7 \\
\hline $27 \mathrm{~h}$ & 3.8 & 3.7 & 3.9 & 3.8 & 3.7 & 3.6 \\
\hline $120 \mathrm{~h}$ & 3.7 & 3.6 & 3.6 & 3.5 & 3.5 & 3.5 \\
\hline
\end{tabular}

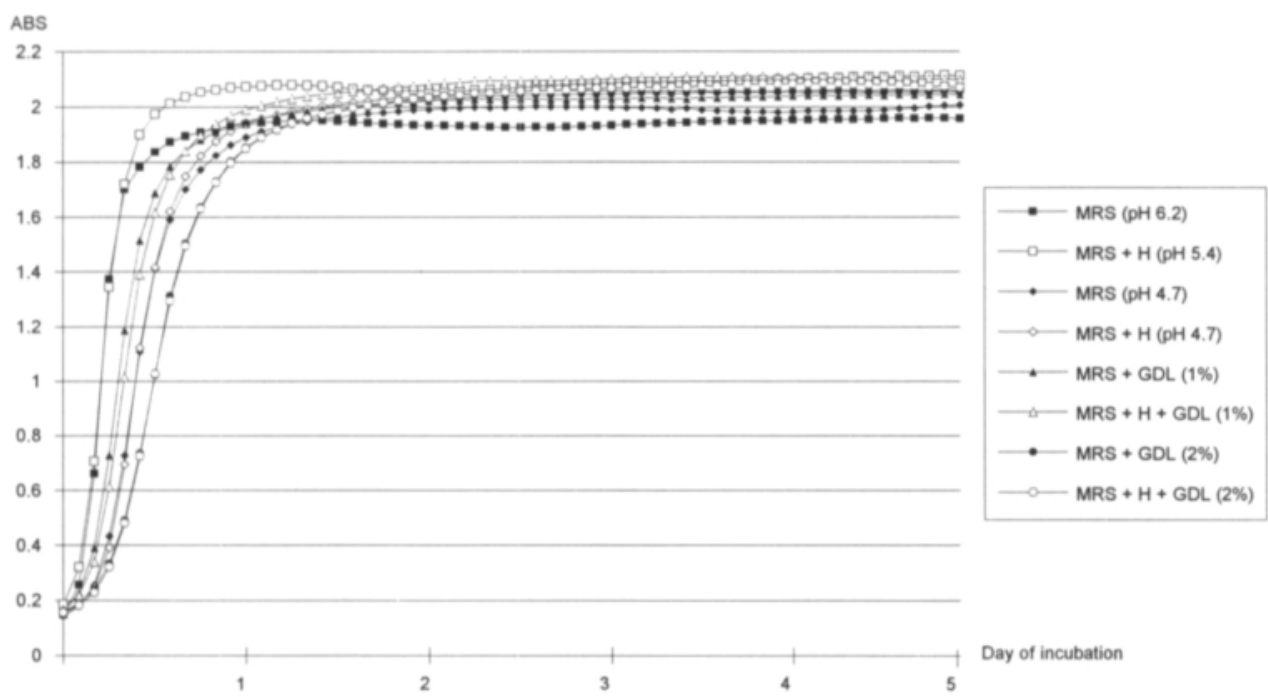

Fig. 3. Growth of strain GS-11 in eight different broth compositions. 


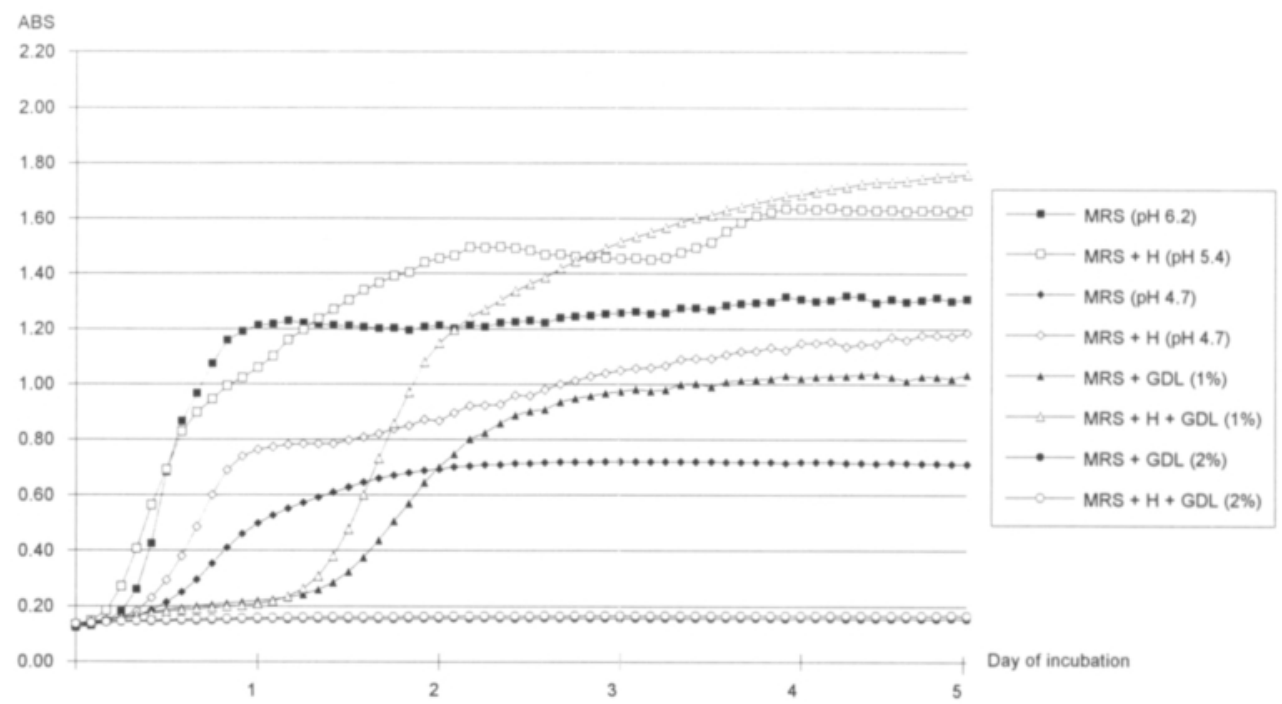

Fig. 4. Growth of strain G-106 in eight different broth compositions.

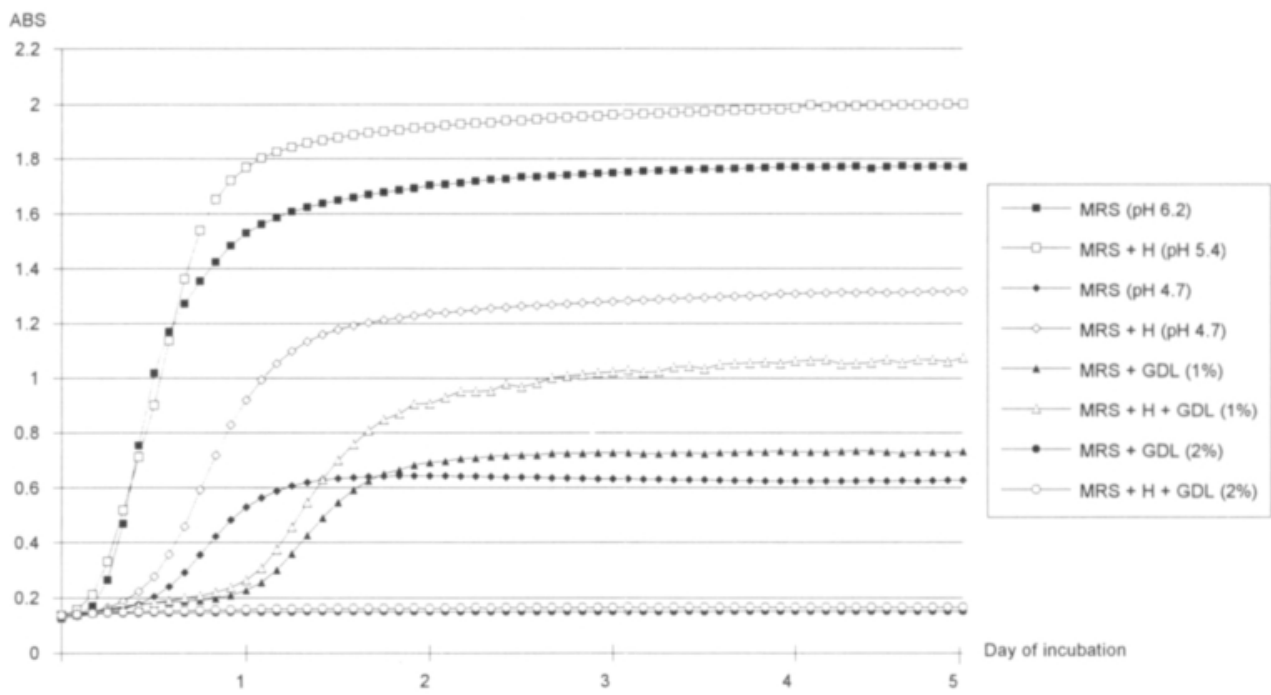

Fig. 5. Growth of strain G-261 in eight different broth compositions.

\section{Discussion}

In this study, histamine was only detected in the second trial, in which the number of $\mathrm{LAB}$ was higher than in the first trial. This conforms with the results of KRANNER et al. (1991). These authors reported that the formation of undesirably high amounts of histamine is dependent on a sufficiently high number of histamine-producing microorganisms and on the presence of free histidine as substrate. Furthermore it is influenced by the storage temperature and by the freshness of the meat used for production. TSCHABRUN et al. (1990) also found more $\mathrm{LAB}$ and total bacteria in dry sausages with 
high histamine content than in those with low histamine. These authors could reduce the histamine content also by using very fresh meat.

EITENMILLER et al. (1978) reported that the use of Pediococcus cerevisiae decreased the formation of tyramine in dry sausages. On the basis of brandspecific studies of retail sausages, TAYLOR et al. (1978) also proposed that proper control of natural fermentation could largely prevent histamine formation. In the present study there were no great differences between the starter cultures studied concerning amines formed during ripening. However, it was interesting that even if the starter cultures used were histamine- and tyramine-negative in vitro, the lowest levels of histamine were found in sausages fermented by Baktoferment $61+$ GDL or by the starter cultures containing LAB with GDL addition.

This phenomenon may be explained by the fact that the amine-positive NSLAB strains did not tolerate acidic conditions as well as the aminenegative starter culture in pure culture studies. This is reasonable because one of the most important criteria for the selection of starter strains has been their good lactic acid production capacity coupled with acid tolerance. Because the accelerated $\mathrm{pH}$ decrease caused by GDL addition increased the lag time and decreased the growth rate of NSLAB strains, it is probable that their number will remain lower for a longer time in sausages with GDL addition. This gives the starter culture the opportunity to outgrow the histamine-positive NSLAB strains. Because the main increase in histamine is detected during the first two weeks (TSCHABRUN et al. 1990) it is probable that the decrease in the number of e.g. histamine-positive strains during this period decreases the histamine levels detected in the final product.

Acknowledgements. We thank Lea Anttalainen and Maire Siberg for technical assistance in the laboratory. This study was supported by the Food Research Foundation, Finland, and the Academy of Finland.

\section{References}

Askar, A. \& Treptow, H. 1986. Biogene Amine in Lebensmitteln. Vorkommen, Bedeutung und Bestimmung. 197 p. Eugen Ulmer GmbH \& Co, Stuttgart.

Bauer, F. von, Tschabrun, R. \& Sick, K. 1989. Histamin in Rohwürsten österreichischer Herkunft. Wien. Tierärztl. Mschr. 76: 180-184.

BJeldanes, L.F., Schutz, D.E. \& Morris, M.M. 1978. On the aetiology of scombroid poisoning: cadaverine potentiation of histamine toxicity in the guinea-pig. Food Cosmet. Toxicol. 16: 157-159.

Eerola, S., Hinkkanen, R., Lindfors, E. \& Hirvi, T. 1993. Liquid chromatographic determination of biogenic amines in dry sausages. JAOAC (in press).

Ettenmiller, R.R., Koehler, P.E. \& Reagan, P.E. 1978. Tyramine in fermented sausages: factors affecting formation of tyrosine and tyrosine decarboxylase. J. Food Sci. 43: 689-693.

IENISTEA, C. 1971. Bacterial production and destruction of histamine in foods, and food poisoning caused by histamine. Die Nahrung 15: 109-113.

ISO 4832. (E) Microbiology - General guidance for the enumeration of coliforms - Colony count technique. 1991.

Kranner, P., Bauer, F. \& Hellewig, E. 1991. Investigations on the formation of histamine in raw sausages. 37th International Congress of Meat Science and Technology, Kulmbach, Germany. Div. 6, 12: 889-891.
LOCKE, F.-K. \& Hechelmann, H. 1986. Starterculturen für Rohwurst und Rohschinken. Fleischwirtsch. 66: 154166.

Löthy, J. \& Schlatter, C. 1983. Biogene Amine in Lebensmitteln: Zur Wirkung von Histamin, Tyramin und Phnylethylamin auf den Menschen. Z. Lebensm. Unters. Forsch 177: 439-443.

MAGA, J.A. 1978. Amines in foods. CRC Critical Reviews in Food Science and Nutrition, Dec: 373-403.

MAIJALA, R. 1993. Formation of histamine and tyramine by some lactic acid bacteria in MRS-broth and modified decarboxylation agar. Letters in Appl. Microbiol. (in press).

— \& Eerol.A, S. 1993. Contaminant lactic acid bacteria of dry sausages produce histamine and tyramine. Meat Science (in press).

— , Eerola, S., Ано, M. \& Hirn, J. 1993. The effect of GDL-induced $\mathrm{pH}$ decrease on the formation of biogenic amines in meat. J. Food Protect. (in press).

MoNERET-VAUTRIN, D.A. 1985. Intolerance of amines and additives. 13th intrenational congress of nutrition, London. p. 746-749.

NiINIVAaRA, F.P. 1955. Über den Einfluss von Bakterienreinkulturen auf die Reifung und Umrötung der Rohwurst. Acta Agralia Fennica 85, 1.

NCFA 68. Determination of fecal streptococci in foods. 1978. 
NuRmi, E. 1966. Effect of bacterial incoulations on characteristics and microbial flora of dry sausage. Acta Agralia Fennica 108, 1.

Pechanek, U., Pfannhauser, W. \& Woichik, H. 1983. Untersuchung über den Gehalt biogener Amine in vier Gruppen von Lebensmitteln des Österreichischen Markets. Lebensm. Unters. Forsch. 176: 335-340.

Pfannhauser, W. \& Pechanek, U. 1984. Biogene Amine in Lebensmitteln: Bildung, Vorkommen, Analytik und toxikologische Bewertung. Z. ges. Hyg. 30: 66-76.

RAMANTANIS, S.V. 1982. Untersuchungen zur Bildung biogener Amine in Rohwursten. 171 p. Inaugural-dissertation zur Erlangung des Grades eines doctor medicinae veterinariae durch die Tierärtzliche Hochschule Hannover.

Rice, S., EItenmiller, R.R. \& Koehler, P.E. 1975. Histamine and tyramine content of meat products. J. Milk. Food Technol. 38: 256-258.

Sмттн, T.A. 1981. Amines in food. Food Chemistry 6: 169200.

TAYlor, S.L., LeAtherwood, M. \& Lieber, E.R. 1978. A survey of histamine levels in sausages. J. Food Protect. 41: 634-637.

TAYLOR, S.L. 1983. Monograph of histamine. Codex alimentarius commission, FAO, WHO. Codex committee on food hygiene, 19th session, Washington, D.C. p. 1-47.

Tschabrun, R., Sick, K., Bauer, F. Kranner, P. 1990. Bildung von Histamin in schnittfesten Rohwürsten. Fleischwirtsch. 70: 448-451.

VANDEKERCKHOVE, P. 1977. Amines in dry fermented sausage. J. Food Sci. 42: 283-285.

WORTBERG, B. \& WOLler, R. 1982. Zur qualität und Frische von Felisch und Fleischwaren im Hinblick auf ihren Gehalt an biogenen Aminen. Fleischwierschaft 62: 1457 1463.

Manuscript received April 1993

Riitta Maijala

Susanna Eerola

Esko Nurmi

National Veterinary and Food Institute

P.O. Box 368

FIN-00101 Helsinki, Finland

Pauli Hill

College of Veterinary Medicine

P.O. Box 6

FIN-00581 Helsinki, Finland

\title{
SELOSTUS
}

\section{Eräiden heräteviljelmien ja glukono-delta-laktonin vaikutus biogeenisten amiinien muodostumiseen kestomakkaroissa}

\author{
Rittta Maijala, Susanna Eerola, Pauli Hill ja Esko Nurmi \\ Eläinlääkintä- ja elintarvikelaitos ja Eläinlääketieteellinen korkeakoulu
}

Tutkimuksessa selvitettiin viiden heräteviljelmän ja glukonodelta-laktonin (GDL) vaikutusta biogeenisten amiinien muodostumiseen kestomakkaroissa fermentaation aikana. Makkarat valmistettiin pilottehtaassa kahdesta eri raaka-aine-erästä ja niitä fermentoitiin $7 \mathrm{vk}$ ajan. Heräteviljelmien välillä ei todettu suuria eroja biogeenisten amiinien pitoisuuksissa. Matalimmat histamiinimäärät olivat makkaroissa, jotka oli fermentoitu GDL:n ja stafylokokkien avulla yhdessả tai ilman maitohappobakteereita. Raaka-aineista peräisin olevien maitohappobakteerien todettiin puhdasviljelmätutkimuksissa olevan heräteviljelmäkantaa herkempiä happamille olosuhteille de Man-RogosaSharpe -liemessä (MRS-liemi). Histidiinilisä $(2 \%)$ sai aikaan selvän histamiinin tuoton kasvun histamiinipositiivisella kannalla (1-2:sta mg/l 6000:aan mg/l). GDL:n lisääminen histidiinipitoiseen liemeen vähensi kuitenkin histamiinin muodostumista selvästi $(54 \mathrm{mg} / \mathrm{l})$. Näiden tulosten perusteella näyttää siltä, että nopeutettu pH:n lasku GDL:n avulla vähentää histamiinin muodostumista kestomakkaroissa ja MRS-liemessä. Erot pH:n laskussa voivat olla yksi selittävả tekijä kauppamakkaroissa todettujen histamiinipitoisuuksien suurelle vaihtelulle. 